\title{
Comparative Performances of Improved Poultry Breeds under Intensive Condition in Murshidabad District of West Bengal, India
}

\author{
Amitava Roy ${ }^{1 *}$, Partha Sarathi Roy ${ }^{1}$, Nilanjan Mandal ${ }^{2}$, \\ Sandeep Kumar ${ }^{3}$ and Pankaj Kumar Biswas ${ }^{4}$ \\ ${ }^{1}$ Murshidabad Krishi Vigyan Kendra, Murshidabad-742135, West Bengal, India \\ ${ }^{2}$ Office of Block Livestock Development Officer, Bhagwangola-1, Murshidabad-742135, \\ W. B., India \\ ${ }^{3}$ Department of Livestock Products Technology, West Bengal University of Animal and \\ Fishery Sciences, West Bengal-700037, India \\ ${ }^{3}$ West Bengal University of Animal and Fishery Sciences, West Bengal-700037, India \\ *Corresponding author
}

\section{A B S T R A C T}

The study was conducted to compare the production performance of Gramariya, Vanaraja, Haringhata Black and Rhode Island Red chickens in intensive condition. The study was

Keywords

Gramapriya, Body

weight, Egg

Production, Intensive

System, Murshidabad

Article Info

Accepted:

16 May 2018

Available Online:

10 June 2018 undertaken in Murshidabad Krishi Vigyan Kendra of West Bengal state with respect to live body weight in different age, age at sexual maturity, average weight at first egg, average egg production up to 72 weeks of age and average egg weight at 40 weeks. The average body weight at onset of laying of Vanaraja birds was $1747.8 \mathrm{~g}$ which was highest than other breeds. Average age at sexual maturity ware 187, 195, 173 and 181 days in Gramapriya Vanaraja, Haringhata Black and Rhode Island Red breeds respectively. The average weight at first egg was highest $(51.2 \mathrm{~g})$ in Vanaraja but lowest $(41.4 \mathrm{~g})$ in Haringhata Black chicken whereas average weight of egg at 40 wks was highest (55.2 g) in Gramapriya but lowest $(47.6 \mathrm{~g})$ in Haringhata Black chicken. The egg production up to 72 wks of age was 153 nos in Gramapriya and 140, 136 and 129 nos in Vanaraja, Rhode Island Red and Haringhata Black birds respectively. Moreover, Gramapriya was genetically superior to Vanaraja, Rhode Island Red and Haringhata Black in terms of productive and reproductive parameters.

\section{Introduction}

Livestock and poultry sector provide a major contribution to India's economy (Nath et al., 2012). Backyard poultry production in India is characterized by small scavenging operations. For generations, farmers of India have practiced this type of rearing and most of the poultry in the villages are indigenous birds, considered to be very poor layers (annual egg production: 50-60 nos.). The native chicken varieties adopted in free- range backyard conditions for centuries contribute about $11 \%$ of total egg production in India (Kumaresan et al., 2008). Therefore, to increase the productivity of backyard poultry farming, the improved varieties which are lookalike indigenous chickens are now being massively introduced in the region (Singh et al., 2002). Grampriya and Vanaraja are dual purpose 
breeds developed at Project Directorate on Poultry for backyard poultry production in rural and tribal areas (Reddy et al., 2002). Haringhata Black chicken (native breeds of West Bengal) is indigenous to India and they have black Plumage, disease resistance and well adaptability to local environment (Vij et al., 2015). Due to interventions of many Govt./Non-Govt. institutes for last couple of decades, local farmers of the district adopted Rhode Island Red (RIR) birds as a better alternative to Desi (Non-Descript) poultry birds. However, production potential of RIR breed seems to be capped in low input farming system (Dumrya 2015). The purpose of this study was to compare and evaluate the productive and reproductive performance, as well as body weight in different age, age at sexual maturity and egg production of Gramariya, Vanaraja, Haringhata Black and Rhode Island Red breeds under intensive management system of rearing in Murshidabad.

\section{Materials and Methods}

\section{Study Area}

The present experiment was conducted at Demonstration Unit of Murshidabad Krishi Vigyan Kendra (KVK) under West Bengal University of Animal and Fishery Sciences, Kolkata, during October, 2015 to April, 2017 to investigate the poultry body weights, age at sexual maturity and production traits of Gramariya, Vanaraja, Haringhata Black and Rhode Island Red (RIR) under intensive condition.

\section{Experiment Design}

Under the intensive system of rearing one hundred and twenty pullets were housed in deep litter system with three replications of ten birds from each breed. Chicks were obtained from Government/private farms, reared in brooding shed of KVK up to 3 weeks of age. All the birds received a standard pullet rearing ration up to 21 weeks of age and thereafter a standard layer diet (Table 1) containing $17.3 \%$ crude protein (CP) and 10.6 MJ ME/kg. Layer birds (after 21 weeks) fed with restricted diet at the rate of $120 \mathrm{~g}$ per adult bird per day and water were supplied adlibitum. Routine deworming and vaccination schedule were followed in flocks as per standard protocol. Data on egg production, egg weight and feed consumption were collected till the layers were 72 weeks old. All the data were summarized by 28 day intervals and submitted to analysis of variance (Steel and Torrie 1960).

\section{Results and Discussion}

Live body weight in different age, age at sexual maturity, average weight at first egg, average egg productions up to 72 weeks of age and average egg weight at 40 weeks of four breeds were presented in the Table 2. It clearly indicated that Vanaraja poultry breed (Fig.1) was the fastest growing breed and it achieved higher body weight (1747.8 g) at maturity followed by Gamapriya (1659.6 g), Rhode Island Red (RIR) (1320.2 g) and Haringhata Black $(1133.0 \mathrm{~g})$ breeds. Hens from Haringhata Black breed showed slowest growth that is common in indigenous lines. Hassen et al., (2006) and Alam et al., (2014) reported similar slow growth pattern of adult non-descript local hens in Ethiopia and Bangladesh respectively. Thakur et al., (2006) suggested that famous Kadaknath breed reared under tribal villages in central India exhibited similar growth pattern like Haringhata Black breed. Adult body weight of RIR breed was also in agreement with Hassen et al., (2006). In the present study, adult body weight of Vanaraja breed was recorded lower as compared to earlier reports (Pathak and Nath 2013) that stated its average adult body weight was $2300 \mathrm{gm}$. This variation might be attributed to different management practices adopted and local climatic variations. 
Table.1 Composition of experimental diet

\begin{tabular}{|r|l|c|}
\hline S. No. & \multicolumn{1}{|c|}{ Ingredient } & \% \\
\hline $\mathbf{1}$ & Grind Yellow Wheat & 49.65 \\
\hline $\mathbf{2}$ & Grind Mustard oil cake & 11.00 \\
\hline $\mathbf{3}$ & Fish Meal (53\% protein) & 9.00 \\
\hline $\mathbf{4}$ & Rice Polish & 22.25 \\
\hline $\mathbf{5}$ & Oyster Shell & 7.50 \\
\hline $\mathbf{6}$ & Mineral - Vitamin Premix* & 0.30 \\
\hline $\mathbf{7}$ & Table Salt & 0.30 \\
\hline
\end{tabular}

* The commercial mineral vitamin Premix (Supplevite-M) supplied per kg of diet: Vitamin A, 500000 IU; Vit. D3, 100000 IU; Vitamin B2, 0.2 g; Vitamin E, 75 Units; Vitamin K, 0.1 g; Cal. Pantothenate, 0.25 g; Nicotinamide, 1 g; Vitamin B12, $0.6 \mathrm{mg}$; Choline Chloride, $15 \mathrm{~g}$. Mineral element: calcium, $75 \mathrm{mg}$; manganese, $2.75 \mathrm{~g}$; iodine, $0.1 \mathrm{~g}$; iron, $0.75 \mathrm{~g}$; zinc, $1.5 \mathrm{~g}$; copper, $0.2 \mathrm{~g}$; cobalt, $0.045 \mathrm{~g}$.

Table.2 Comparative performances of different breeds of poultry

\begin{tabular}{|l|}
\hline Performances \\
\hline Body Weight (g) \\
a. At Hatch \\
b. 8 week \\
\hline c. 16 week \\
d. At the Onset of Laying \\
\hline Average age at sexual \\
maturity (days) \\
\hline Average weight of first egg \\
(g) \\
\hline $\begin{array}{l}\text { Average egg production up to } \\
72 \text { weeks (Nos.) }\end{array}$ \\
\hline Average egg weight at 40 \\
weeks (g)
\end{tabular}

\begin{tabular}{|c|c|c|c|}
\hline Gramapriya & Vanaraja & Haringhata Black & Rhode Island Red \\
\hline 37.2 & & & \\
341.8 & 41.0 & 31.6 & 33.4 \\
1101.4 & 1159.4 & 293.4 & 325.2 \\
1659.6 & 1747.8 & 679.8 & 989.2 \\
\hline 187 & 195 & 1133.0 & 1320.2 \\
\hline 49.8 & 51.2 & 41.4 & 181 \\
\hline 153 & 140 & 129 & 45.4 \\
\hline 55.2 & 53.6 & 47.6 & 136 \\
\hline & & & 53.8 \\
\hline
\end{tabular}

Fig.1 Body weight of Vanaraja poultry

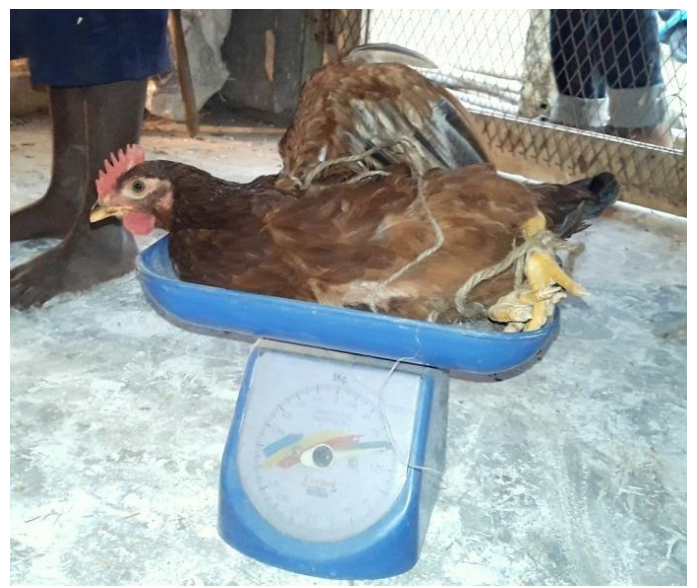


Haringhata Black was the fastest (173 days) to reach sexual maturity among four breeds and that was found to be similar to that of local non-descript hens of Bangladesh as reported by Alam et al., (2014). The differences in attaining sexual maturity might be due to the genetic differences among the four groups of birds. Sexual maturity tends to be attained at later ages for heavier breeds. This character is also influenced by many environmental factors, such as temperature, nutrition and day length.

The average weight of first egg were $49.8 \mathrm{~g}$, $51.2 \mathrm{~g}, 41.4 \mathrm{~g}$ and $45.4 \mathrm{~g}$ but average egg weight at 40 weeks were $55.2 \mathrm{~g}, 53.6 \mathrm{~g}, 47.6$ $\mathrm{g}$ and $53.8 \mathrm{~g}$ in case of Gramariya, Vanaraja, Haringhata Black and Rhode Island Red respectively. In general the egg weights in both the period (first egg \& at 40 weeks) were significantly higher in Gramapriya and Vanaraja with better egg weights in compare to Haringhata Black and Rhode Island Red during the entire laying period. However, the egg weights in Haringhata Black are significantly lower than the other 3 breeds. Sharma and Hazary (2002) reported 42-44 g (40 weeks) of egg weight in Vanaraja and an average egg weight of $53.55 \mathrm{~g}$ in Gramapriya, which were lower than the present estimates. The higher production in Gramapriya may be because of the parental lines utilized in developing breeds.

Egg production and egg weights determine the success of the poultry enterprise. In intensive system the highest egg production (up to 72 weeks) was obtained by Gramapriya with 153 nos followed by Vanaraja (140 nos), Rhode Island Red (136 nos) and Haringhata Black (129 nos). Each genotype showed distinct egg production performance. All the four breeds produced eggs in one or two clutches. Egg production performance of RIR was in agreement with earlier workers (Hassen et al., 2006; Taj et al., 2014). It is clear from the data that Gramapriya followed by Vanaraj are the most suitable for rearing even in restricted or low feed input farming.

It may be concluded that Gramapriya is genetically superior to Vanaraja, Rhode Island Red and Haringhata Black in terms of above reproductive parameters like age at sexual maturity and productive parameters like egg production, egg weight, hatch weight and body weight. In the intensive system of rearing the highest performance was obtained with Gramapriya, which is considered to be well adapted to the climatic conditions of Murshidabad district. Government and NonGovernment organizations must initiate for large scale propagation of this Gramapriya breed for achieving better livelihood in the concerned region.

\section{References}

Alam M. A., M. S. Ali, N. G. Das and M. M. Rahman. 2014. Present Status of Rearing Backyard Poultry in Selected Areas of Mymensingh District. Bangladesh Journal of Animal Science. 43(1): 30-37.

Dumrya S. 2015. Characterization of backyard poultry farming in Indian Sundarban region. Indian Journal of Poultry Science. 50(1): 90-95.

Hassen H., F. W. C. Neser, A. Kock and E. Van Marle-Kosterv. 2006. Growth performance of indigenous chickens under intensive management conditions in Northwest Ethiopia. South African Journal of Animal Science. 36: 71-73.

Kumaresan A., K. M. Bujarbaruah, K. A. Pathak, B. Chettri, S. K. Ahmed and S. Haunshi. 2008. Analysis of a village chicken production system and performance of improved dual purpose chickens under a subtropical hill agroecosystem in India. Tropical Animal Health and Production. 40: 395-402. 
Nath B. G., P. K. Pathak and A. K. Mohanty. 2012. Constraints Analysis of Poultry Production at Dzongu Area of North Sikkim in India. Iranian Journal of Applied Animal Science. 2(4): 397-401.

Pathak P. K. and B. G. Nath. 2013. Rural poultry farming with improved breed of backyard chicken. Journal of World's Poultry Research. 3: 24-27.

Reddy M. R., G. N. Rao, R. P. Sharma, B. L. N. Reddy, B. R. Gupta and A. Satyanarayana. 2002. Genetic study on juvenile traits of Vanaraja chickens. Indian Journal of Animal Science. 74(12): 1229-1231.

Sharma R. P. and R. C. Hazary. 2002. In: Proceedings of National Workshop on characterization and conservation of indigenous poultry germplasm. Central Agricultural Research Institute, Andaman. 104-113.

Singh R. V., V. K. Saxena and D. Sharma. 2002. Technological developments in the poultry sub-sector; In technology options for sustainable livestock production in India. Proceedings of the workshop on Documentation, Adoption and Impact of Livestock Technologies in India. 99-103.

Steele R. G. D. and J. H. Torrie. 1960. Principles and Procedures of Statistics. McGraw-Hill, New York. 106-110.

Taj H. M., M. K. Taj, I. Taj and Z. Samreen. 2014. Backyard Poultry in Balochistan. International Journal of Medical Science and Innovative Research. 10(2): 364-366.

Thakur M. S., S. N. S. Parmar and P. V. A. Pillai. 2006. Studies on growth performance in Kadaknath breed of poultry. Livestock Research for Rural Development. 18(8): 01-09.

Vij P. K, M. S. Tantia and S. Pan. 2015. Performance of Harringhata Black chicken under field conditions. Indian Journal of Animal Science. 85(8): 930932.

\section{How to cite this article:}

Amitava Roy, Partha Sarathi Roy, Nilanjan Mandal, Sandeep Kumar and Pankaj Kumar Biswas. 2018. Comparative Performances of Improved Poultry Breeds under Intensive Condition in Murshidabad District of West Bengal, India. Int.J.Curr.Microbiol.App.Sci. 7(06): 1504-1508. doi: https://doi.org/10.20546/ijcmas.2018.706.178 